\title{
A FUTURE OF INTERNATIONAL COPYRIGHT? BERNE AND THE FRONT DOOR OUT
}

\author{
AN ESSAY IN HONOUR OF SAM RICKETSON
}

By Rebecca Giblin ${ }^{1}$

In press: Across Intellectual Property (Cambridge University Press, 2019)

\section{The unamendable treaty}

The Berne Convention was always intended to be revised regularly to keep pace with technological and social change. ${ }^{2}$ There were seven revisions in its first 85 years, with the longest pause being the 20 years between the Rome (1928) and Brussels (1948) Acts, at which time the world was understandably preoccupied with other matters. But progress ground to a halt in 1971. Since then, we have gone almost half a century with no substantive revision at all.

That can be attributed, in part, to the procedure involved. Revising Berne's substantive provisions requires a unanimity of votes cast, effectively giving each member a veto right and making change exponentially more difficult as membership grows. As I write there are 176 contracting parties, with three - the tiny Pacific Island nations of Tuvalu, the Cook Islands and Kiribati - joining in 2017 alone. But sheer numbers aren't the only problem. More significant is the chasm between members' interests, particularly developed and developing nations, which has significantly affected Berne's development since the post-colonial era following World War II. In the lead up to that period, as chronicled by Ricketson and Ginsburg in their history

\footnotetext{
${ }^{1}$ Associate Professor, Faculty of Law, Monash University; ARC Future Fellow; CREATe Fellow. This work was supported by ARC grant FT170100011. I developed these ideas over many enjoyable hours of debate with Sam Ricketson and Jane Ginsburg in New York during late 2017 - thanks to both for your generosity. Some of the ideas I touch on are developed more deeply elsewhere: see Rebecca Giblin, 'A New Copyright Bargain? Reclaiming Lost Culture and Getting Authors Paid' (2018) 41 Columbia Journal of Law \& the Arts 369. ${ }^{2}$ Sam Ricketson and Jane C Ginsburg, International Copyright and Neighbouring Rights: The Berne Convention and Beyond (Oxford: Oxford University Press, $\left.2^{\text {nd }} \mathrm{ed}, 2006\right) 340$ citing Berne Convention for the Protection of Literary and Artistic Works, opened for signature 9 September 1886, 828 UNTS 221 (entered into force 5 December 1887) art 17 (which envisaged amendment of the Treaty to introduce improvements to 'perfect' the system) ('Berne Convention').
} 
of Berne, successive revisions had expanded rights and made the treaty 'increasingly less congenial to the interests of developing countries'. ${ }^{3}$ By 1967, such nations comprised more than 40 per cent of the membership, and they were visibly chafing at what Drahos describes as a system 'run by an Old World club of former or diminished colonial powers to suit their economic interests'. ${ }^{4}$ The poorer nations began raising increasingly urgent questions about the impact of Berne on their development agendas, and there emerged a real risk that they would withdraw from the Berne Union altogether. In a nod to the justice of their claims, the 1967 Revision contained a Protocol that allowed greater flexibility to developing nations, including over the making of translations and copies. ${ }^{5}$ However, powerful publisher and author groups mobilised resistance to the reforms and the Protocol was ultimately abandoned, creating a schism which threatened for years to destroy the Union. ${ }^{6}$ The wounds were sutured, barely, by the 1971 Paris Act. Its substitute Appendix offered up less generous concessions that every member was, however grudgingly, then able to live with, and the Union held.

In the immediate wake of these events emerged a strong view that further revision should not or could not be attempted. Koumantos, in the 'should not' camp, argued that the Berne Convention already gave authors essentially everything they needed, and that to open it up for further revision would be to peek into Pandora's box. 'Authors have no reason to ask for a revision of the Berne Convention - not even in order to complete or clarify certain points. This is because once the procedure of revision is begun once can never know what will come out of it. ${ }^{7}$ Sam was of the view that revision, however desirable, simply could not be achieved. While he did nominate a wish list of future changes to Berne in his 1987 treatise, it was combined with an observation that a revision conference in the short to medium term would be 'pointless' ${ }^{8}$ Later, he wrote that 'the prevailing view [after 1971] was that there would be no more revisions of the old kind, and that it would thereafter remain unchanged, a kind of

\footnotetext{
3 Ricketson and Ginsburg, above n 2, 884.

${ }^{4}$ Peter Drahos with John Braithwaite, Information Feudalism: Who Owns the Knowledge Economy? (London: Earthscan, 2002) 76.

${ }^{5}$ Berne Convention, revised at Stockholm, 14 July 1967 ('Stockholm Act') annex (Protocol Regarding Developing Countries).

${ }^{6}$ Ricketson and Ginsburg, above n 2, 913-914. These events have been described as a 'crisis in international copyright': see Howard D Sacks, 'Crisis in International Copyright: The Protocol Regarding Developing Countries' [1969] Journal of Business Law 26, 128.

${ }^{7}$ Georges Koumantos, 'The Future of the Berne Convention' (1986-1987) 11 Columbia VLA Journal of Law \& the Arts 225, 236.

${ }^{8}$ Sam Ricketson, The Berne Convention for the Protection of Literary and Artistic Works: 1886-1986 (London: Centre for Commercial Law Studies, Queen Mary College, Kluwer, 1987) 919.
} 
enduring artifact to a particular conception of authors' rights that could be taken no further in the changing circumstances of the late twentieth century'?

Treaty obsolescence doesn't necessarily result in pain for treaty parties. Even if members don't wish to formally renounce their obligations, it's not uncommon for outdated parts of toothless treaties to be quietly abandoned. Berne, long regarded as 'little more than a code of polite behaviour', ${ }^{10}$ might have met that fate had the formal linking of IP and trade by the Agreement on Trade-Related Aspects of Intellectual Property Rights (TRIPS Agreement) ${ }^{11}$ not set it on a different course. That change in fortunes came quickly. In 1988, stronger IP rights were identified as a United States (US) trade priority. After that, industry and governmental discussions about an IP agreement as part of the Uruguay round of the General Agreement on Tariffs and Trade (GATT) rapidly gained momentum, and copyright was put into play as part of a complex bargain entwining such disparate areas as agriculture, textiles and access to medicines. The speed with which the copyright aspects were settled is enough to make one blink. Cornish observed that 'the allure of freer global trading under a revised GATT' was 'scarcely foreseeable in 1986 ' ${ }^{12}$ and Sam has admitted some embarrassment for mentioning the emerging issue only in passing in his 1987 text. And yet by 1990, drafts of what would become TRIPS already incorporated Berne as the base on which additional 'Berne-plus' rights were negotiated, and the copyright text was essentially settled by late 1991 . Given the pace at which events developed, it's perhaps not surprising that the parties adopted an existing text as a baseline. Additions were tacked on to resolve some of the urgent controversies of the day, such as whether to protect computer programs as literary works. But TRIPS' biggest revolution lay in enforceability. TRIPS took that 'code of polite behaviour' and gave it real teeth, rendering enforceable virtually the whole via World Trade Organization (WTO) dispute resolution mechanisms.

\footnotetext{
${ }^{9}$ Sam Ricketson, 'The Berne Convention: The continued relevance of an ancient text' in David Vaver and Lionel Bently (eds), Intellectual Property in the New Millennium: Essays in Honour of William R Cornish (Cambridge: Cambridge University Press, 2004) 217, 217-218.

${ }^{10}$ William R Cornish, 'Foreword' in Ricketson and Ginsburg, above n 2, v.

${ }^{11}$ Marrakesh Agreement Establishing the World Trade Organization, opened for signature 15 April 1994, 1867 UNTS 3 (entered into force 1 January 1995) annex 1C ('Agreement on Trade-Related Aspects of Intellectual Property Rights') ('TRIPS Agreement').

${ }^{12}$ Cornish, above n 10.
} 


\section{New wine into old bottles}

The dangers of that elevation were readily apparent even before TRIPS was formally agreed. Writing in 1992, Sam observed that 'the older and established regimes are now unmistakably beginning to show increasing strains when faced with the problems posed by technological progress'. ${ }^{13}$ He saw a lesson in a cautionary Biblical parable: 'Neither do men put new wine into old bottles: else the bottles break and the wine runneth out, and the bottles perish: but they put new wine into new bottles, and both are preserved. ${ }^{14}$ The story references the practice of storing wine in animal skins, which dried out as they aged. Those old skins could no longer expand as the fermenting wine released gas - and unfortunate explosions ensued. Sam was warning that copyright's skins were growing dangerously brittle, even as the world was trying to lock itself into their continued use. Heedless, world governments formally agreed to TRIPS two years later. With adoption of Berne's outdated and unamendable rules becoming a condition of unprecedented access to world trade markets, its membership exploded by more than 200 per cent from its centenary figure of 86 .

To be fair, at that time the full significance of the dawning information age was probably not yet fully appreciated. After all, in 1994, less than half a per cent of the world's population yet had access to the internet; little of the world's culture had been digitised and the potentialities of digital abundance yet to become apparent. ${ }^{15}$ But by 1995, Sam was already warning that 'the norms now embodied in TRIP[S] (and in Berne) are in danger of becoming outdated and irrelevant in the face of the challenges posed by digital technology, the convergence of technologies and communications, and the emergence of the information superhighway'. ${ }^{16}$ Perhaps, as he suggested, a new paradigm of copyright protection may have already been required. It was too bad, then, that the world had just doubled down on the old ways of doing things.

Those old ways are based on assumptions formed in the world we used to inhabit. ${ }^{17}$ Berne and TRIPS reflect a paradigm where marginal costs of copying and distribution were so high that

\footnotetext{
${ }^{13}$ Sam Ricketson, 'New wine into old bottles: Technological change and intellectual property rights' (1992) 10(1) Prometheus 53, 54.

${ }^{14}$ Matthew, chapter IX, verse 17.

${ }^{15}$ Exploring the significance of the evolution from scarcity to abundance, see generally Mark Lemley, 'IP in a World Without Scarcity' (2015) 90(2) NYU Law Review 460.

${ }^{16}$ Sam Ricketson, 'The Future of the Traditional Intellectual Property Conventions in the Brave New World of Trade-Related Intellectual Property Rights' (1995) 26 IIC 872, 898.

${ }^{17}$ For fuller development of these outdated assumptions, see Giblin, above n 1.
} 
most works were lost within a few short years of publication. In that context there was little downside in the wholesale grant of inordinate terms that would almost certainly outlast their owners' interest, since all but the most popular would be quickly lost regardless. At the same time, formalities on exercise and enjoyment of rights were necessarily onerous and expensive, and a blanket prohibition made sense to prevent authors from being unfairly burdened.

Today those assumptions no longer hold good (at least for those of us with digital access). We have the ability to copy and distribute many kinds of work globally, instantaneously, and at a marginal price close to zero. In this paradigm, there's a real cost to the grant of broad and long rights regardless of whether their owners want them, need them, or even know they exist. Online connectivity has also changed the costs and benefits of registration so fundamentally that we have reached a point (as I have argued elsewhere) that Berne's prohibition on formalities, intended to support authors, has become a key barrier to reforms that could secure them a fairer share. ${ }^{18}$ In sum, Berne's rules were designed for a different world, and were locked in and given teeth just as realisation was beginning to dawn about the realities of this new one.

So here we are, a quarter of a century after TRIPS was agreed, almost half a century since Berne's last substantive revision, and still using those same old bottles. As they detonate around us, the occasion of Sam's Festschrift seems the ideal occasion to ask: just what are we going to do with all this wine?

\section{Our options are limited}

Currently, Berne/TRIPS severely constrain the universe of possibles. Copyright law would undoubtedly look very different if we were to design it from scratch today. ${ }^{19}$ However, the chances of any wholesale revision of Berne are vanishingly small, given the vast number of members, the chasm between their interests, and the structure that gives even the single-most-

\footnotetext{
${ }^{18}$ Giblin, above $\mathrm{n} 1$.

${ }^{19}$ See generally Rebecca Giblin and Kimberlee Weatherall (eds), What if we could reimagine copyright? (Acton: ANU Press, 2017).
} 
tiny a right to veto. Indeed, that combination makes even minor revisions look seemingly impossible to achieve..$^{20}$ TRIPS has proved effectively unamendable as well. ${ }^{21}$

That could change. US President Donald Trump has been repeatedly threatening to withdraw the US from the WTO, and at the time of writing, the US is deliberately undermining the organisation by refusing to fill its appeals court vacancies. ${ }^{22}$ If the WTO fails, all bets are off. However, barring any such upheaval of global political and trading frameworks, Berne/TRIPS look set to define the outer bounds of copyright for the foreseeable future. Sam recently confirmed his view of past decades, writing in 2018: 'it may be accepted that revision of the Berne text presently remains highly unlikely - to quote a leading character in an iconic Australian film, "You're dreaming!",23

Assuming revision won't happen, states can't simply create a new club with different rules, either: Berne's article 20 only permits members to enter into other international agreements to the extent they grant authors more extensive rights or do not derogate from what is already granted under Berne. That limits parties to 'special agreements' such as the World Intellectual Property Organization (WIPO) Copyright Treaty (WCT), which, though explicitly responding to the need 'to provide adequate solutions to the questions raised by new economic, social, cultural and technological developments', ${ }^{24}$ could not meaningfully do so, since any amendments had to fall within Berne's existing strictures. Article 20 was perhaps taken as far as it could be with the 2013 Marrakesh Treaty, ${ }^{25}$ which focused on enabling, rather than limiting, use of works. But still, it could not go beyond the limits set out in Berne itself.

\footnotetext{
${ }^{20}$ Cf Daniel Gervais, (Re)structuring Copyright: A Comprehensive Path to International Copyright Reform (Northampton, MA: Edward Elgar, 2017); Alan Story, 'Burn Berne: Why the Leading International Copyright Convention Must be Repealed' (2003) 40(3) Houston Law Review 763.

${ }^{21}$ Rebecca Giblin and Kimberlee Weatherall, 'A collection of impossible ideas' in Giblin and Weatheral, above n 19, 315, 322-323.

22 See e.g., Rosalind Mathieson, 'US Block of WTO Appeals Body Compromises System, Director Says' Bloomberg (online), 9 November 2017<https://www.bloomberg.com/news/articles/2017-11-08/u-s-block-ofwto-appeals-body-compromises-system-azevedo-says >; 'Disaster Management: The WTO is under threat from the Trump administration' The Economist (online), 7 December 2017<https://www.economist.com/news/leaders/21732108-america-increasingly-resorting-bilateral-trademeasures-wto-under-threat $>$.

${ }^{23}$ Sam Ricketson, 'The International Framework for the Protection of Authors: Bendable Boundaries and Immovable Obstacles' (2018) 41 Columbia Journal of Law \& the Arts 341, 353.

${ }^{24}$ WIPO Copyright Treaty, opened for signature 20 December 1996, 2186 UNTS 121 (entered into force 6 March 2002) Preamble.

${ }^{25}$ Marrakesh Treaty to Facilitate Access to Published Works for Persons Who Are Blind, Visually Impaired or Otherwise Print Disabled, opened for signature 27 June 2013, WIPO Doc VIP/DC/8 (entered into force 30 September 2016).
} 
Individual nations might derogate from Berne/TRIPS regardless, gambling that their actions won't be challenged. As Taubman has explained, TRIPS breaches don't necessarily result in enforcement action:

Compliance with WTO standards is not like policing a parking lot, where an enforcement officer will issue a ticket and impose a penalty for non-compliance - or a speed camera that will routinely issue a penalty for any infringement. Non-compliance with TRIPS does not bring automatic penalties, and normally does not even yield a formal finding of non-compliance. The only way of reaching an official determination of non-compliance is if another country is concerned about IP protection to the extent that they are prepared to initiate a legal complaint and follow it right through to its conclusion. $^{26}$

Naturally, political and pragmatic considerations will factor heavily in deciding whether to take such action. Despite early fears that TRIPS would unleash a tsunami of litigation, few derogations have actually attracted an enforcement response to date. For example, various developing nations have departed from Berne/TRIPS in furtherance of their development programs $^{27}$ (those hard-wrung concessions of the Berne Appendix ultimately proving so unhelpful that they have been implemented virtually nowhere $\left.{ }^{28}\right)$. So far that has been without formal comebacks in the WTO. However, such tactics will work only where that overall political and pragmatic calculus suggests enforcement is not worthwhile. More fundamental reforms, those with the potential to threaten the most powerful beneficiaries of the existing framework, would be much more likely to trigger a response. That's likely one reason why we haven't yet seen any attempts at real paradigmatic reform.

A more radical option would be to renounce Berne altogether. That option is easily dismissible however, since it would mean the loss of reciprocal international protection for domestic works (and could not even re-enliven the Universal Copyright Convention, given that treaty's special

\footnotetext{
${ }^{26}$ Antony Taubman, A practical guide to working with TRIPS (Oxford: Oxford University Press, 2011) 13-14.

${ }^{27}$ Alberto Cerda Silva, 'Beyond the Unrealistic Solution for Development Provided by the Appendix of the Berne Convention on Copyright' (2013) 60 Journal of the Copyright Society of the USA 581, 598-605.

${ }^{28}$ See e.g., Ricketson and Ginsburg, above n 2, 957; Margaret Chon, 'Copyright and capability for education: an approach "from below"' in Tzen Wong and Graham Dutfield (eds), Intellectual Property and Human Development: Current Trends and Future Scenarios (New York: Cambridge University Press, 2011) 218, 230, 233; Lea Shaver, 'Copyright and inequality' (2014) 92 Washington University Law Review 117, 148.
} 
clauses applying to former Berne nations ${ }^{29}$ ). It's also impossible without abandoning TRIPS and the WTO, and hence losing access to vital world trading markets. While it is now thinkable (if not expected) that the WTO system might soon come to an end, in part because of the US actions described above, just now withdrawal is still simply not an option for virtually any member - as suggested by the fact that, at time of writing, no member ever has. ${ }^{30}$

So Berne/TRIPS are effectively unamendable, they block derogatory agreements, and leaving isn't (yet) an option. Ignoring them can be a rational tactic, but would be highly perilous in the case of paradigmatic reforms that threaten to tread on powerful toes. Does this mean we're left with no options while the bottles explode around us, other than to continually lament, in any discussion of meaningful reform, 'But Berne won't let us do that'?

\title{
Berne's 'front door out'
}

No, there is at least one other alternative - to take Berne's front door out.

Berne was only ever intended to regulate members' treatment of other members' nationals, and so gives states an entitlement to depart from Berne minima with regard to works 'first published' within their borders. ${ }^{31}$ However, it has long been assumed that Berne's standards are definitionally more advantageous to authors, and thus that members would rarely (if ever) choose to exercise this right. For example, Ginsburg writes:

\begin{abstract}
Although neither [Berne nor TRIPS] prescribes the level of protection a member State must afford authors whose works were first published in that State, most countries, wary of treating their own authors worse than foreign authors, end up incorporating the international norms in to domestic legislation. ${ }^{32}$
\end{abstract}

Nations should rightly be wary of giving less preferential treatment to their own authors. But as we have seen, the world has changed almost beyond recognition since Berne's rules were

\footnotetext{
${ }^{29}$ Universal Copyright Convention, opened for signature 6 September 1952, 216 UNTS 132 (entered into force 16 September 1955) Appendix Declaration Relating to Article XVII.

${ }^{30}$ Full list of members and observers at World Trade Organization, Understanding the WTO: Members and Observers <https://www.wto.org/english/thewto_e/whatis_e/tif_e/org6_e.htm>.

${ }^{31}$ Berne Convention art 5(1).

32 Jane C Ginsburg, 'Contracts, Orphan Works, and Copyright Norms: What Role for Berne and TRIPs?' in Rochelle Cooper Dreyfuss, Harry First and Diane Leenheer Zimmerman (eds), Working Within the Boundaries of Intellectual Property: Innovation Policy for the Knowledge Society (Oxford: Oxford University Press, 2010) 471, 483 (emphasis added).
} 
put in place, and many of its underlying assumptions no longer hold good. That makes it timely to also challenge the orthodoxy that domestic Berne departure must be definitionally worse for authors. Elsewhere, I recently built the case that elements of national departure from Berne minima could be the key to creating an alternative copyright bargain that could solve some of copyright's most persistent failures. I sketched a system that more clearly delineated between copyright's incentives and rewards components, envisaged use of formalities-supported reversion to better secure the rewards share to authors, and - again utilising registration permitted broader use of no-longer-wanted-but-still-copyrighted works in a system analogous to a domaine public payant. ${ }^{33}$ That analysis showed how departures from Berne's prohibition on formalities on exercise and enjoyment of rights (and potentially its limits on exceptions and compulsory licensing) could, if carefully tailored, significantly improve authors' remuneration outcomes in ways that aren't otherwise possible, upending the assumption that Berne departure would necessarily make them worse off. And it demonstrated how, simultaneously, it was possible to reclaim much of the value and culture lost under current approaches. This cracks open a path to a real alternative - for nations to sidestep Berne's most crippling barriers by taking advantage of their right to domestically depart from its minima; to take the front door out. Doing so would mean retaining the benefits of reciprocal global protection and access to world markets, while regulating their own works and authors in ways that better reflect current realities and take advantage of copyright's non-zero-sum nature.

My 'front door out' also raises a number of mind-bending new questions - such as, how would the principle of national treatment work where a nation's departure from Berne minima makes domestic authors better off, rather than worse? And what would article 19's preservation of claims to the benefit of 'greater protection ... granted by legislation in a country of the Union', mean for foreign authors where that greater protection could require departure from Berne? There's not space to address these questions here, but they're tasty fodder for chewing another day.

\section{Could the 'front door out' be subverted?}

Of course, any solution that depends on elements of domestic departure will make crucial determination of works' country of origin - and therein raise possibilities for subversion.

\footnotetext{
${ }^{33}$ Giblin, above $\mathrm{n} 1$.
} 
Article 5(4) of Berne states that a work's country of origin is the country where it is first published, or, where it is published simultaneously (that is, within 30 days of first publication ${ }^{34}$ ) in multiple Union countries, by the country with the shortest term. The losers in any alternative copyright bargain involving elements of domestic Berne departure would likely seek to bypass it by manipulating the country of first publication and taking the 'back door' in to treatment as a foreign work. If they were simply first published in Country B at least 30 days before publishing in Country A, would that force Country A to afford its own nationals' works treatment as foreign works? If so, it would seriously undermine the strategy's feasibility.

For a few compelling reasons however, it seems unlikely that article 5 could be so subverted. Berne does not specify what happens where a work's country of origin differs from an author's country of nationality. ${ }^{35}$ It has been argued that such cases might be treatable as having two countries of origin, that is, that of first publication and that of nationality. ${ }^{36}$ As explained by Ginsburg and Ricketson, 'the basis of the suggestion is the assumption that the Berne Convention is not to be interpreted as breaking the bonds between Union countries and their citizens, as it is only concerned with the relations of Union countries to foreign authors' ${ }^{37}$

If a member was to adopt this interpretation, and regulate its own nationals' works regardless of place of first publication, it would seem exceedingly unlikely to be challenged via WTO dispute settlement mechanisms. That is not only because of the political and pragmatic considerations canvassed above, but also because Berne's clear intent to reserve to members the right to regulate their own nationals would make it difficult to prove both breach and damage.

There's another critical reason too why it's unlikely that any nation would push for enforcement of Berne's country of origin principles precisely as written. Recall that, when a work is simultaneously published in multiple Union countries (defined in article 3(4) as occurring within 30 days of first publication), the country of origin is the one with the shortest term. Where simultaneously published in Union and non-Union countries, the country of origin

\footnotetext{
${ }^{34}$ Berne Convention art 3(4).

${ }^{35}$ Ricketson and Ginsburg, above n 2, 283.

${ }^{36}$ Ibid., 283-284, citing Alfred Baum, 'Völkerrecht, Berne Konvention und Landesgesetze' [1950]

Gewerblicher Rechtsschutz und Urheberrecht 437, 451; Wilhelm Nordemann, Kai Vinck, Paul W Hertin, and Gerald Meyer, International Copyright and Neighbouring Rights Law (New York: VCH,1990) 75.

${ }^{37}$ Ricketson and Ginsburg, above n 2, 284.
} 
is the Union country. ${ }^{38}$ This text was designed and adopted in a 1960s world. What happens when we apply it to the one we inhabit today, by enquiring into the country of origin for works first published online? Such works are typically made accessible globally within moments, to Union and non-Union countries alike. If online publication amounts to simultaneous first publication in every country from which it may be accessed, then a plain English reading suggests every Union member with the shortest term will be a country of origin. That was the reasoning of a US district court in Kernal Records $v$ Mosley, which held that the online first publication of music (on an Australian website) meant that the work was simultaneously published in the US, and thus ought to be treated as a local US work. ${ }^{39}$ If every shortest-term member is the country of origin of every internet work, that means every one of those countries of origin will have the ability to depart from its minima. Thus, a literal application of Berne's text raises the possibility of blowing the whole Berne system up. This would no doubt give pause to any copyright-exporting nations who might otherwise be tempted to argue against an interpretation permitting fellow members to regulate their own nationals. The absurdity of that literal reading also further demonstrates how unmoored Berne has become from today's realities.

A study group of the International Literary and Artistic Association (ALAI) has sought to avoid such an interpretation by arguing that Berne's article 3(3) requires the distributed copies to be in physical form:

We infer this from the words 'manufacture of copies' ... and the term 'availability of such copies' (emphasis supplied), which would seem to refer back to the material copies that are made available by the author or authorized intermediary distributor. ... [T]he conclusion that the copies envisioned in article 3(3) are pre-existing physical copies also follows from the comparison of the first and second phrases of art 3(3): the exclusion from the definition of 'published works' of literary or artistic works

\footnotetext{
${ }^{38}$ Berne Convention art 5(4).

${ }^{39}$ Kernal Records Oy v Mosley, 794 F Supp 2d 1355, 1360 (SD Fla 2011). On appeal, the $11^{\text {th }}$ Circuit was not convinced the relevant publication had in fact occurred online, but nonetheless indicated online distribution on a public website was consistent with a presumption of simultaneous worldwide availability: Kernel Records Oy $v$ Mosley, 694 F 3d 1294, 1306 (11 ${ }^{\text {th }}$ Cir, 2012).
} 
communicated by wire or broadcasting casts doubt on the characterization of works 'made available' to the public over digital networks as 'published. ${ }^{\text {40 }}$

However, this attempted fix surfaces fresh difficulties. For one thing, article 3(3)'s own text specifies that "published works" means works published with the consent of their authors, whatever may be the means of manufacture of the copies ... ${ }^{41}$ The inclusiveness of that language cuts against ALAI's proposed technologically-specific reading. For another, this reading would still result in numerous countries of origin, especially given growing use of print-on-demand. Further, ALAI's proposed interpretation would lead to absurdities of its own: works distributed exclusively in digital form (as is increasingly the case) would never be 'first published' anywhere. Their authors would be obliged to rely on article 5(4)(c)'s rules governing unpublished works, which provide that, for most works, the country of origin is the country of the author's nationality. ${ }^{42}$ While this would at least preserve nations' rights to regulate the works of their own nationals, it creates new difficulties for authors of non-Union members, who might then lack a requisite point of attachment. It also raises further difficult questions in cases where digitally-distributed works have multiple authors. ${ }^{43}$ While the ALAI Study Group acknowledges these difficulties, it argues that 'the seemingly counter-intuitive result that a work disseminated only in dematerialized digital format is never "published" is the less problematic outcome'. ${ }^{44}$ Ricketson and Ginsburg have separately argued that, in the case of simultaneous publication online in a number of countries, it might make sense to have a reading that designates the country of origin as the country of the author's nationality. ${ }^{45}$

\section{Extending the benefits of domestic departure from Berne}

All this should provide considerable comfort to any nation which, looking for ways past the obstacles imposed by Berne's outdated strictures, chooses to depart from them for its own nationals (even as it flags a fresh danger emerging from Berne's obsolescence). However, that still only takes us so far. Since copyright is territorial, enacting countries could only apply such systems within their own borders. There, too, they could defeat attempts to subvert them

\footnotetext{
${ }^{40}$ Country of Origin Study Group of the International Literary and Artistic Association (ALAI), Determination of country of origin when a work is first publicly disclosed over the internet (14 January 2012) $<$ http://www.alai.org/en/assets/files/resolutions/country-of-origin.pdf> 2-3.

${ }^{41}$ Berne Convention art 3(3) (emphasis added).

42 Berne Convention art 5(4)(c).

${ }^{43}$ ALAI Country of Origin Study Group, above n 40, 5-8.

${ }^{44}$ Ibid., 5.

${ }^{45}$ Ricketson and Ginsburg, above n 2, 285.
} 
through adoption of the contract law of foreign jurisdictions. ${ }^{46}$ But private international law problems would inevitably plague any attempt to enforce Berne-departing copyright laws beyond their own borders. Could the potential benefits of domestic Berne departure nonetheless be extended?

We have seen that article 20 prohibits international agreements that derogate from Berne's minima. Significantly however, it does nothing to prevent nations from agreeing to each regulate their own nationals in a harmonised way that involves elements of permitted Berne departure. This opens the possibility of countries banding together to individually depart from Berne for their own nationals, where overall that would result in a better deal. Harmonised, cooperative, front door departure could potentially achieve widespread benefits of a kind currently beyond reach. For example, participants could each create appropriate domestic registries to facilitate rights clearance and payment. If designed for compatibility and then internationally shared, that could soon result in a comprehensive database of the type currently ruled out by Berne/TRIPS. Similarly, if nations with shared interests and language were to mandate harmonised author protective mechanisms, this could contribute greatly to efforts to secure their own creators a fairer share.

Weatherall and I once described the Berne/TRIPS framework as a 'hostage situation we can't see anyone walking away from' ${ }^{47}$ Right now, the existence of the 'front door out' does nothing to change that. It would take enormous political will to reallocate copyright's rights and responsibilities to take advantage of copyright's zero-sum nature and better reflect today's realities. Any government considering such an approach would have to face down strong resistance from trading partners and corporations with vested interests in the existing ways of doing things. It will take time before competing motivations might become strong enough to surmount such pressures. Eventually however, we may reach a point where individual nations can no longer afford the waste generated by regulating the digital world with mechanical rules. If and when we are finally ready to take authors' interests seriously, reclaim our lost culture and retire that despairing lament of 'but Berne doesn't let us do that' - the front door will be there.

\footnotetext{
${ }^{46}$ For a general discussion of private international law issues arising in the copyright context, including territorial complexities introduced by the Internet, see Jane C Ginsburg and Pierre Sirinelli, 'Private International Law Aspects of Authors' Contracts: The Dutch and French examples' (2015) 39 Columbia Journal of Law and the Arts 171.

${ }^{47}$ Giblin and Weatherall, above n 21, 321.
} 